\title{
Genetic alterations in gliosarcoma and giant cell glioblastoma
}

Ji Eun Oh ${ }^{1}$, Takashi Ohta ${ }^{1,2}$, Naosuke Nonoguchi ${ }^{1,3}$, Kaishi Satomi ${ }^{1}$, David Capper ${ }^{4}$, Daniela Pierscianek ${ }^{1,5}$, Ulrich Sure ${ }^{5}$, Anne Vital ${ }^{6}$, Werner Paulus ${ }^{7}$, Michel Mittelbronn $^{8}$, Manila Antonelli ${ }^{9}$, Paul Kleihues ${ }^{10}$, Felice Giangaspero ${ }^{9,11}$, Hiroko Ohgaki $^{1}$

${ }^{1}$ Section of Molecular Pathology, International Agency for Research on Cancer, F69372 Lyon, France; ${ }^{2}$ Department of Neurological Surgery, Nihon University School of Medicine, Tokyo, Japan; ${ }^{3}$ Department of Neurosurgery, Osaka Medical College, Takatsuki, Japan; ${ }^{4}$ Department of Neuropathology, Ruprecht-Karls Universität Heidelberg and DKFZ, Im Neuenheimer Feld 224, 69120 Heidelberg, Germany ${ }^{5}$ Department of Neurosurgery, University Hospital Essen, Essen, Germany; ${ }^{6}$ Bordeaux Institute of Neuroscience, CNRS UMR 5227, F-33076 Bordeaux, France; ${ }^{7}$ Institute of Neuropathology and University Hospital Munster, D-48149 Munster, Germany; ${ }^{8}$ Institute of Neurology (Edinger Institute), Goethe-University, Frankfurt/Main, Germany; ${ }^{9}$ Department of Experimental Medicine, Rome University, La Sapienza, I-0151 I-86077 Rome Italy, ${ }^{10}$ Medical Faculty, University of Zurich, CH8091 Zurich, Switzerland; ${ }^{11}$ IRCCS Neuromed Pozzilli, I-86077Rome, Italy

Key words: Gliosarcoma, giant cell glioblastoma, IDH mutation, TERT mutation, 19q, $10 \mathrm{q}$

Running title: Gliosarcoma and giant cell glioblastoma

Correspondence to:

Dr Hiroko Ohgaki

Head, Molecular Pathology Section

International Agency for Research on Cancer

150 Cours Albert Thomas 69372 Lyon, France

Tel: +33(0)4 72738534

Fax: +33 (0)4 72738698

E-mail: ohgaki@iarc.fr

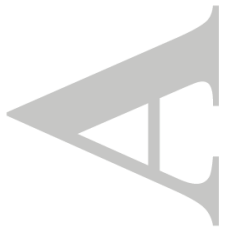

This article has been accepted for publication and undergone full peer review but has not been through the copyediting, typesetting, pagination and proofreading process which may lead to differences between this version and the Version of Record. Please cite this article as an 'Accepted Article', doi: 10.1111/bpa.12328 


\section{Abstract}

The majority of glioblastomas develop rapidly with a short clinical history (primary glioblastoma $I D H$ wild-type), whereas secondary glioblastomas progress from diffuse astrocytoma or anaplastic astrocytoma. IDH mutations are the genetic hallmark of secondary glioblastomas. Gliosarcomas and giant cell glioblastomas are rare histological glioblastoma variants, which usually develop rapidly. We determined the genetic patterns of $\underline{36}$ gliosarcomas and 19 giant cell glioblastomas. IDH1 and IDH2 mutations were absent in all $\underline{36}$ gliosarcomas and in 18 of 19 giant cell glioblastomas analyzed, indicating that they are histological variants of primary glioblastoma. Furthermore, $\mathrm{LOH} 10 \mathrm{q} \underline{(88 \%)}$ and TERT promoter mutations $\underline{(83 \%)}$ were frequent in gliosarcomas. Copy number profiling using the 450k methylome array in 5 gliosarcomas revealed CDKN2A homozygous deletion ( 3 cases), trisomy chromosome 7 ( 2 cases), and monosomy chromosome 10 (2 cases). Giant cell glioblastomas had LOH $10 q$ in $50 \%$ and LOH $19 q$ in $42 \%$ of cases. ATRX loss was detected immunohistochemically in $19 \%$ of giant cell glioblastomas, but absent in 17 gliosarcomas. These and previous results suggest that gliosarcomas are a variant of, and genetically similar to, primary glioblastomas, except for a lack of EGFR amplification, while giant cell glioblastoma occupies a hybrid position between primary and secondary glioblastomas.

\section{INTRODUCTION}

Glioblastoma (WHO grade IV) is the most frequent and malignant glioma. The majority of glioblastomas (>90\%) develop rapidly after a short clinical history, without evidence of a less malignant precursor lesion (primary glioblastoma). In contrast, secondary glioblastomas develop through progression from diffuse astrocytoma (WHO grade II) or anaplastic astrocytoma (WHO grade III) $(24,27,28)$. The decisive genetic alterations that reliably distinguish between primary and secondary glioblastoma are IDH mutations $(3,24,28,35,37)$ which constitute a reliable genetic marker of secondary glioblastoma. In a large population-based study, IDH1 mutation status corresponded to the respective clinical diagnosis in $95 \%$ of cases $(24,28)$.

Gliosarcoma and giant cell glioblastoma are rare histological variants of glioblastoma (16). On clinical grounds, they are considered variants of primary glioblastoma, but genetic data that would allow an unambiguous classification are still scant. Gliosarcomas constitute approximately $2 \%$ of all glioblastomas (16), and are characterized by a biphasic tissue pattern with alternating areas displaying glial or mesenchymal differentiation (16). Despite these two distinct histological components, gliosarcomas are considered monoclonal, since glial and mesenchymal tumor areas were usually found to be genetically similar $(4,31)$. It has been reported that PTEN 
mutations $(37-45 \%)$ and $p 16^{\text {INK4a }}$ homozygous deletion $(37 \%)$ are common, TP53 mutations (24-26\%) less frequent, and EGFR amplification rare or absent $(0-8 \%)(1$, 31).

Giant cell glioblastomas constitute up to $5 \%$ of all glioblastomas, and are characterized by a predominance of bizarre, multinucleated giant cells with an occasionally abundant reticulin network (16). TP53 mutations are frequent (78-90\%) and PTEN mutations are common (33\%), but EGFR amplification and $p 16^{\text {INK4a }}$ homozygous deletion have been reported to be rare $(17,18,30)$.

The objectives of the present study are to further genetically characterize these glioblastoma variants. We screened $\underline{36}$ gliosarcomas and 19 giant cell glioblastomas for IDH1 and IDH2 mutations (genetic hallmarks of secondary glioblastoma), and various additional genetic alterations known to be operative in diffuse gliomas.

\section{MATERIALS AND METHODS Tumor samples}

Formalin-fixed and paraffin embedded tissue samples of $\underline{36}$ gliosarcomas were obtained from the Neurological Institute (Edinger Institute), University Hospital Frankfurt, Germany, the Institute of Neuropathology, University Hospital Munster, Germany, the Department of Neuropathology, University Hospital Rome, Italy, the Institute of Neuroscience, Bordeaux, France, and the Department of Neuropathology, University Hospital Zurich, Switzerland. Formalin-fixed tissue samples of 19 giant cell glioblastomas, as well as a frozen sample of a giant cell glioblastoma were obtained from the Department of Neuropathology, University Hospital Zurich, Switzerland, the Institute of Neuropathology, University Hospital Munster, Germany, and the Departments of Neuropathology and Neurosurgery, University Hospital Essen, Germany.

Gliosarcomas and giant cell glioblastomas were diagnosed according to the 2007 WHO Classification (16). Histologically, gliosarcomas showed the typical biphasic pattern with alternating areas of glial and mesenchymal differentiation (Fig. 1A). The glial area was composed of anaplastic glial cells with GFAP expression, and the mesenchymal component demonstrated bundles of spindle cells with malignant transformation and abundant connective tissue stained by reticulin, without GFAP expression (Fig. 1B). For selection of giant cell glioblastomas, care was taken to include only typical cases showing a predominance of multinucleated, GFAP positive tumor cells in at least one large area of the biopsy specimen. All gliosarcomas and 18 giant cell glioblastomas were located in cerebral hemispheres; one giant cell glioblastoma was in the thalamus. This study was approved by the International Agency for Research on Cancer (IARC) Ethics Committee. 


\section{DNA extraction}

Genomic DNA was extracted from typical tumor areas that were scraped from formalin-fixed and paraffin-embedded tissue slides or cryostat section from a frozen sample as previously described $(23,29)$. DNA concentration and purity were measured by a ND8000 spectrophotometer (NanoDrop Technologies, Wilmington, DE, USA).

\section{IDH mutations}

Screenings for the IDH1 and IDH2 mutations were performed in $\underline{36}$ gliosarcomas and 19 giant cell glioblastomas by Sanger sequencing as described previously $(24,35)$.

\section{TERT promoter mutations}

Sequences covering the mutational hotspots (C228T and C250T) in the TERT core promoter were amplified by nested PCR. Primer sequences and detailed protocols were reported previously (25). We considered as TERT mutations only cases when the height of the mutated allele was $>20 \%$ of that of the wild-type allele on sequencing data, as previously described (25).

\section{LOH 1p, 19q, 10q}

Quantitative PCR was performed to assess $\mathrm{LOH} 1 \mathrm{p}, 19 \mathrm{q}$, and $10 \mathrm{q}$ in $\underline{17}$ gliosarcomas and 12 giant cell glioblastomas. Microsatellite markers were D1S214, D1S468, and D1S2736 at 1p36.32-1p36.22, D19S408, D19S596, and D19S867 at $19 q 13.31-19 q 13.33$, D10S536 at 10q23.3, and D10S1683 at 10q24.2 (22, 26). We interpreted as LOH when 2 or 3 markers for each chromosome suggested loss, as described previously $(22,26)$.

\section{ATRX immunohistochemistry}

ATRX immunohistochemistry was carried out in 17 gliosaromas and in 16 giant cell glioblastomas. Paraffin sections were deparaffinized in xylene and $95 \%$ ethanol for 5

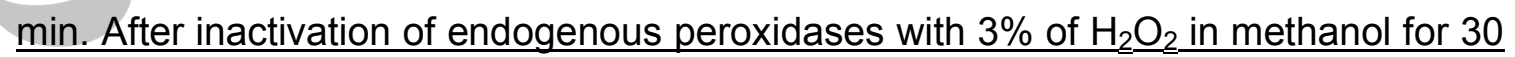
min, sections were incubated in epitope retrieval solution (diluted 1:10, H-3300, Low $\mathrm{pH}$ 6.0, Vector Laboratories, inc. Burlingame, CA, USA) for $20 \mathrm{~min}$ at $95-99^{\circ} \mathrm{C}$. Sections were cooled for $40 \mathrm{~min}$ at room temperature, and were incubated with antiATRX antibody (1:400, HPA001906, rabbit polyclonal, Sigma-Aldrich, St. Louis, MO, USA), diluted in antibody diluent (S3022, Dako, Les Ulis, France) at $4^{\circ} \mathrm{C}$ overnight. Sections were then washed in phosphate buffered saline (PBS) and incubated with the second antibody (EnVision+Single Reagents HRP rabbit, K4002, Dako, Les Ulis, 
France) for $30 \mathrm{~min}$. Visualization was performed using Vector DAB Substrate Kit (SK4100; Vector Laboratories) for $4 \mathrm{~min}$. After washing in PBS, sections were counterstained with hematoxylin.

For optimization of immunohistochemistry protocols, normal human brain tissue was used as a positive control, and human liver tissue was used as a negative control. For interpretation of ATRX immunoreactivity, vascular endothelial cells within tumor tissues on histological slides were used as internal positive controls. Cases with more than $10 \%$ immunoreactive tumor cells were considered as positive as previously described (36)

\section{Methylome and copy number profiling}

The Illumina Infinium HumanMethylation450 (450k) array was used in 5 gliosarcomas, for which sufficient DNA from paraffin sections were available, to obtain the DNA methylation status of 482,421 CpG sites (Illumina, San Diego, CA, USA), according to the manufacturer's instructions at the Core Facility of the DKFZ. The methylation level of each CpG site was represented by beta-values, which ranged from 0 (unmethylated) to 1 (methylated). Genome-wide copy-number profiles were calculated by using the intensity measures of the aforementioned methylation probe loci throughout the genome. Chromosomal copy-number alterations were visualized by the IdeogramBrowser tool (19).

\section{Statistical analysis}

Fisher exact test was performed to evaluate the significance of difference in various genetic alterations. The significance level chosen was $P<0.05$. Statistical analyses were carried out using Stat View J-5.0 software (Abacus Concepts, Berkeley, CA, USA).

\section{RESULTS}

\section{IDH mutations}

IDH1 mutations were absent in all $\underline{36}$ gliosarcomas and in 18 out of 19 giant cell glioblastomas analyzed. One giant cell glioblastoma with an IDH1 (R132S) mutation was diagnosed in a 44 year-old male patient, who developed anaplastic astrocytoma one year earlier. TP53 mutation (R280T) was also detected in both anaplastic astrocytoma and giant cell glioblastoma. IDH2 mutations were absent in all gliosarcomas and giant cell glioblastomas analyzed.

\section{TERT promoter mutations}

TERT promoter mutations were detected in 30 of $36(83 \%)$ gliosarcomas. Of these, 
$\underline{76 \%}$ were $\mathrm{C} 228 \mathrm{~T}$ and $\underline{24 \%}$ were $\mathrm{C} 250 \mathrm{~T}$. This ratio was similar to that reported in primary glioblastomas (25).

For the 20 selected gliosarcomas, we carried out screening for TERT promoter mutations separately in glial and mesenchymal components, and found identical results in 19 cases. In one gliosarcoma, TERT mutation was observed in only the mesenchymal component, but not in the glial component.

TERT promoter mutations (C228T) were found in 4 of $16(25 \%)$ giant cell glioblastomas.

\section{LOH 1p, 19q, 10q}

Quantitative PCR revealed LOH $1 \mathrm{p}$ in $1 / \underline{17(6 \%)}$ gliosarcomas and in 2 of $12(17 \%)$ giant cell glioblastomas. LOH 19q was detected in 3 gliosarcomas $(3 / 17 ; 18 \%)$ and 5 giant cell glioblastomas $(5 / 12 ; 42 \%)$. LOH 10q was detected in $15 / 17$ gliosarcomas $(88 \%)$ and in 6 of $12(50 \%)$ giant cell glioblastomas. Co-deletion of $1 p / 19 q$ was detected in $1 / 17(6 \%)$ gliosarcomas and in $2 / 12(17 \%)$ giant cell glioblastomas.

\section{ATRX immunohistochemistry}

Loss of nuclear ATRX expression was observed in 3 of $16(19 \%)$ giant cell glioblastoma, but in none of the 17 gliosarcomas analyzed.

ATRX was expressed in vascular endothelial cells (internal positive control) in all histological sections. Sections without ATRX antibodies showed no immunoreactivity.

\section{Copy number profiling}

Copy number plots generated from $450 \mathrm{k}$ methylation data in 5 gliosarcomas revealed CDKN2A homozygous deletion (3 cases), monosomy chromosome 10 (2 cases), trisomy chromosome 7 ( 2 cases), gain at chromosome 7 (one case), and CDK4 amplification (one case).

\section{Comparison of genetic alterations with primary and secondary glioblastomas}

Genetic alterations of the gliosarcomas and giant cell glioblastomas which were obtained in the present study as well as those reported previously are summarized in Table 1. These data were compared with those of the primary glioblastomas $(I D H-$ wild-type) and secondary glioblastomas (IDH mut) reported previously (Table 1) (24, 25).

PTEN mutations in gliosarcomas $(41 \%)$ were significantly more frequent than those in primary glioblastomas $(24 \% ; \underline{P=0.0190)}$ ) and in secondary glioblastomas $(5 \% ; P=0.0001)$. Loss of ATRX expression was less frequent in gliosarcomas than secondary glioblastomas $(P=0.0009)$. TERT promoter mutations in gliosarcomas 
were more frequent $\underline{(83 \%)}$ than those in secondary glioblastomas $(\underline{26} \% ; P<0.0001)$. $\mathrm{LOH} \mathrm{19q}$ was more frequent in gliosarcomas $(18 \%)$ than those in primary glioblastomas (4\%; $P=0.0406)$. LOH $10 q$ was more frequent in gliosarcomas $(88 \%)$ than those in primary glioblastomas $(67 \% ; \underline{P=0.0452)}$.

PTEN mutations in giant cell glioblastomas (33\%) were significantly more frequent than those in secondary glioblastomas $(5 \% ; P=0.0126)$. Loss of ATRX expression was less frequent in giant cell glioblastomas than in secondary glioblastomas $(P=0.0206)$. TP53 mutations were more frequent in giant cell glioblastomas $(84 \%)$ than in primary glioblastomas $(\underline{23} \% ; P<0.0001)$. LOH $19 q$ was more frequent in giant cell glioblastomas $(42 \%)$ than in primary glioblastomas $(4 \%$; $P$ $=0.0002 ;$ Table 1).

\section{DISCUSSION}

IDH1 mutations are the definitive molecular marker of secondary glioblastoma (24, 28). Gliosarcomas and giant cell glioblastomas usually develop rapidly without less malignant precursor lesions (31), and have thus been considered to be primary glioblastomas. There have been few studies on IDH mutations. Lee et al. (13) screened 26 gliosarcomas (21 primary gliosarcomas, 2 progressed from grade II or grade III astrocytomas, 2 developed from glioblastomas; one developed 9 years after radiotherapy for meningioma) for IDH1 mutations. IDH1 mutations were detected in one primary gliosarcoma and in a secondary gliosarcoma that progressed from a grade III astrocytoma (13). Balss et al. (3) reported that 2 of 8 giant cell glioblastomas but none of 5 gliosarcomas carried IDH1 mutations. Lotsch et al. (15) reported the absence of $I D H 1$ mutations in one gliosarcoma and one giant cell glioblastoma.

This study provides evidence that gliosarcoma is indeed a histological variant of primary glioblastoma IDH wild-type. IDH1 and IDH2 mutations were absent in all $\underline{36}$ gliosarcomas analyzed. TERT promoter mutations, which are frequent in primary glioblastomas $(2,25)$, were detected in $\underline{83 \%}$ of gliosarcomas (Table 1). Furthermore, $\mathrm{LOH} 10 \mathrm{q}$ was observed in $15 / 17(88 \%)$ gliosarcomas. Monosomy of chromosome 10 was also observed in 2/5 gliosarcomas in analysis calculated from 450k methylome array. Immunohistochemistry showed that ATRX is expressed in all gliosarcomas, suggesting the absence of ATRX mutations $(14,36)$. Thus, gliosarcomas share clinical and genetic features with primary glioblastomas $I D H$ wild-type. The only major difference was EGFR amplification, which is common in primary glioblastomas and was considered to be a rare event in gliosarcomas $(1,31)$ (Table 1).

Despite two distinct histological components, gliosarcomas are considered monoclonal, since glial and mesenchymal tumor areas were usually found to be genetically similar with respect to TP53 mutations, PTEN mutations, $p 16^{\text {INK4a }}$ 
deletion, EGFR amplification, and $10 \mathrm{q}$ loss $(4,31)$. The present study shows that this is also the case for TERT promoter mutations, as they were present in both glial and mesenchymal tumor areas in 95\% (19/20) of gliosarcomas.

The molecular mechanisms involved in the mesenchymal differentiation in gliosarcomas are not yet fully understood. Expression of several transcription factors (e.g. Slug, Twist, MMPs) associated with epithelial-mesenchymal transition (EMT), was found in mesenchymal tumor areas, suggesting that signalling pathways involved in EMT may play a role in the induction of mesenchymal differentiation (21). In studies using conventional $\mathrm{CGH}$, patterns of chromosomal imbalance were largely similar in glial and mesenchymal tumor areas, but there were also gains and losses at several loci unique to either glial or mesenchymal tumor areas $(1,6)$. Using array $\mathrm{CGH}$, we have shown that in a small fraction of gliosarcomas the gain at 13q13.3q14.1 and expression of several genes (STOML3, FREM2, LHFP) at this locus was restricted to the mesenchymal tumor area of gliosarcomas (20).

Giant cell glioblastomas develop rapidly with a short clinical history, but they occur in young adults (mean, 44 years), similar to secondary glioblastomas IDH mut $(18,30)$. We here provide genetic evidence that giant cell glioblastoma is a histological variant of primary glioblastoma $I D H$ wild-type as IDH1/2 mutations were absent in 18 of 19 giant cell glioblastomas analyzed. However, frequencies of TERT promoter mutations, TP53 mutations, LOH 19q, and EGFR amplification were similar to those of secondary IDH1 mut glioblastomas $(17,18,30)$ (Table 1). Thus, giant cell glioblastoma occupies a hybrid position, sharing with primary glioblastoma a short clinical history, the absence of less malignant lesions, absence of IDH1/2 mutations, frequent PTEN mutations and infrequent ATRX loss. In common with secondary glioblastomas, they have a younger patient age at manifestation, infrequent TERT promoter mutations, frequent TP53 mutations, frequent LOH 19q, and lack of EGFR amplification.

There was the exceptional case of a giant cell glioblastoma IDH1 mut (R132S) with clinical evidence suggesting progression from an anaplastic astrocytoma diagnosed a year earlier. This suggests that rarely, a secondary glioblastoma may show the histologic features of a giant cell glioblastoma.

The molecular mechanisms involved in the giant cell phenotype are not yet fully understood. Temme et al. (34) reported that Aurora B expression is significantly higher in giant cell glioblastomas than in other glioblastomas, and that ectopic overexpression of Aurora B induced a significant increase in the proportion of multinucleated giant cells in TP53 mutant but not in TP53 wild-type malignant glioma cells.

$\mathrm{LOH} 10 \mathrm{q}$ is a frequent genetic alteration in both primary and secondary 
glioblastomas, suggesting that this chromosomal region may contain tumor suppressor gene(s), essential for malignant glioblastoma phenotype $(27,28)$. $\mathrm{LOH}$ $10 \mathrm{q}$ is also associated with shorter survival of glioblastoma patients in both population based $(24,26)$ and hospital-based studies $(7,33)$. We here provide evidence that $\mathrm{LOH} 10 \mathrm{q}$ is the genetic hallmark of gliosarcomas $(88 \%)$ and giant cell glioblastomas (50\%), further suggesting that gene(s) at $10 \mathrm{q}$ play an important role in the pathogenesis of glioblastomas and their variants.

In summary, gliosarcomas and giant cell glioblastomas are both histological variants of primary glioblastoma IDH1 wild-type. The genetic pattern of gliosarcoma is largely similar to that of primary glioblastoma except for a lack of EGFR amplification, while giant cell glioblastoma genetically occupies a hybrid position between primary and secondary glioblastomas. 


\section{Legend to Figures:}

Fig. 1

Gliosarcomas showing the typical biphasic pattern with alternating areas of glial and mesenchymal differentiation (A). Note that the glial area was composed of anaplastic glial cells with GFAP expression, while mesenchymal component lacks GFAP expression (B). Giant cell glioblastoma with multinucleated giant cells (C). GFAP is expressed at different levels in multinucleated giant cells in giant cell glioblastoma (D). Multinucleated giant cells with loss of nuclear ATRX expression in giant cell glioblastoma (E). Another giant cell glioblastoma showing nuclear immunoreactivity to ATRX (F). Arrows indicate nuclear ATRX expression in endothelium served as an internal positive control.

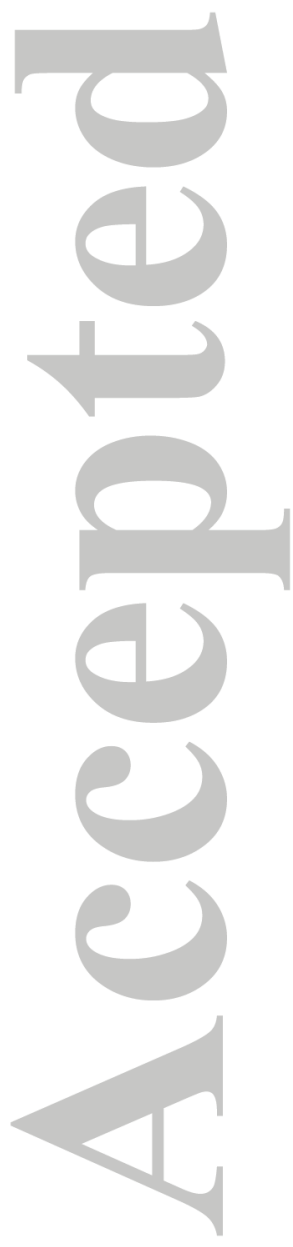




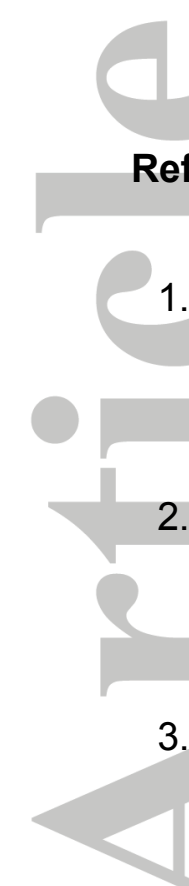

1. Actor B, Cobbers JM, Buschges R, Wolter M, Knobbe CB, Reifenberger G, Weber RG (2002) Comprehensive analysis of genomic alterations in gliosarcoma and its two tissue components. Genes Chromosomes Cancer 34: 416-427

2. Arita H, Narita $Y$, Fukushima S, Tateishi K, Matsushita $Y$, Yoshida A, Miyakita $Y$, Ohno M, Collins VP, Kawahara N, Shibui S, Ichimura K (2013) Upregulating mutations in the TERT promoter commonly occur in adult malignant gliomas and are strongly associated with total $1 \mathrm{p} 19 \mathrm{q}$ loss. Acta Neuropathol

3. Balss J, Meyer J, Mueller W, Korshunov A, Hartmann C, von Deimling A (2008) Analysis of the IDH1 codon 132 mutation in brain tumors. Acta Neuropathol 116: $597-602$

4. Biernat W, Aguzzi A, Sure U, Grant JW, Kleihues P, Hegi ME (1995) Identical mutations of the p53 tumor suppressor gene in the gliomatous and the sarcomatous components of gliosarcomas suggest a common origin from glial cells. J Neuropathol Exp Neurol 54: 651-656

5. Bleeker FE, Atai NA, Lamba S, Jonker A, Rijkeboer D, Bosch KS, Tigchelaar W, Troost D, Vandertop WP, Bardelli A, Van Noorden CJ (2010) The prognostic IDH1( R132 ) mutation is associated with reduced NADP+-dependent IDH activity in glioblastoma. Acta Neuropathol 119: 487-494

6. Boerman RH, Anderl K, Herath J, Borell T, Johnson N, Schaeffer-Klein J, Kirchhof A, Raap AK, Scheithauer BW, Jenkins RB (1996) The glial and mesenchymal elements of gliosarcomas share similar genetic alterations. $J$ Neuropathol Exp Neurol 55: 973-981

7. Brat DJ, Seiferheld WF, Perry A, Hammond EH, Murray KJ, Schulsinger AR, Mehta MP, Curran WJ (2004) Analysis of 1p, 19q, 9p, and 10q as prognostic markers for high-grade astrocytomas using fluorescence in situ hybridization on tissue microarrays from Radiation Therapy Oncology Group trials. Neuro Oncol 6: $96-103$

8. Brennan CW, Verhaak RG, McKenna A, Campos B, Noushmehr H, Salama SR, Zheng S, Chakravarty D, Sanborn JZ, Berman SH, Beroukhim R, Bernard B, Wu CJ, Genovese G, Shmulevich I, Barnholtz-Sloan J, Zou L, Vegesna R, Shukla SA, Ciriello G, Yung WK, Zhang W, Sougnez C, Mikkelsen T, Aldape K, Bigner DD, Van Meir EG, Prados M, Sloan A, Black KL, Eschbacher J, Finocchiaro G, Friedman W, Andrews DW, Guha A, lacocca M, O'Neill BP, Foltz G, Myers J, Weisenberger DJ, Penny R, Kucherlapati R, Perou CM, Hayes DN, Gibbs R, Marra M, Mills GB, Lander E, Spellman P, Wilson R, Sander C, Weinstein J, Meyerson M, Gabriel S, Laird PW, Haussler D, Getz G, Chin L (2013) The somatic genomic landscape of glioblastoma. Cell 155: 462-477 
9. Cerami E, Gao J, Dogrusoz U, Gross BE, Sumer SO, Aksoy BA, Jacobsen A, Byrne CJ, Heuer ML, Larsson E, Antipin Y, Reva B, Goldberg AP, Sander C, Schultz N (2012) The cBio cancer genomics portal: an open platform for exploring multidimensional cancer genomics data. Cancer Discov 2: 401-404

10. Eckel-Passow JE, Lachance DH, Molinaro AM, Walsh KM, Decker PA, Sicotte H, Pekmezci M, Rice T, Kosel ML, Smirnov IV, Sarkar G, Caron AA, Kollmeyer TM, Praska CE, Chada AR, Halder C, Hansen HM, McCoy LS, Bracci PM, Marshall R, Zheng S, Reis GF, Pico AR, O'Neill BP, Buckner JC, Giannini C, Huse JT, Perry A, Tihan T, Berger MS, Chang SM, Prados MD, Wiemels J, Wiencke JK, Wrensch MR, Jenkins RB (2015) Glioma Groups Based on 1p/19q, IDH, and TERT Promoter Mutations in Tumors. N Engl J Med 372: 2499-2508

11. Gao J, Aksoy BA, Dogrusoz U, Dresdner G, Gross B, Sumer SO, Sun Y, Jacobsen A, Sinha R, Larsson E, Cerami E, Sander C, Schultz N (2013) Integrative analysis of complex cancer genomics and clinical profiles using the cBioPortal. Sci Signal 6: I1

12. Ichimura K, Pearson DM, Kocialkowski S, Backlund LM, Chan R, Jones DT, Collins VP (2009) IDH1 mutations are present in the majority of common adult gliomas but rare in primary glioblastomas. Neuro Oncol 11: 341-347

13. Lee D, Kang SY, Suh YL, Jeong JY, Lee JI, Nam DH (2012) Clinicopathologic and genomic features of gliosarcomas. J Neurooncol 107: 643-650

14. Liu XY, Gerges N, Korshunov A, Sabha N, Khuong-Quang DA, Fontebasso AM, Fleming A, Hadjadj D, Schwartzentruber J, Majewski J, Dong Z, Siegel P, Albrecht S, Croul S, Jones DT, Kool M, Tonjes M, Reifenberger G, Faury D, Zadeh G, Pfister S, Jabado N (2012) Frequent ATRX mutations and loss of expression in adult diffuse astrocytic tumors carrying IDH1/IDH2 and TP53 mutations. Acta Neuropathol

15. Lotsch D, Ghanim B, Laaber M, Wurm G, Weis S, Lenz S, Webersinke G, Pichler J, Berger W, Spiegl-Kreinecker S (2013) Prognostic significance of telomerase-associated parameters in glioblastoma: effect of patient age. Neuro Oncol 15: 423-432

16. Louis DN, Ohgaki H, Wiestler OD, Cavenee WK, (Eds) (2007) WHO Classification of Tumours of the Central Nervous System, IARC: Lyon

17. Martinez R, Roggendorf W, Baretton G, Klein R, Toedt G, Lichter P, Schackert G, Joos S (2007) Cytogenetic and molecular genetic analyses of giant cell glioblastoma multiforme reveal distinct profiles in giant cell and non-giant cell subpopulations. Cancer Genet Cytogenet 175: 26-34

18. Meyer-Puttlitz B, Hayashi Y, Waha A, Rollbrocker B, Bostrom J, Wiestler OD, Louis DN, Reifenberger G, von DA (1997) Molecular genetic analysis of giant cell glioblastomas. Am J Pathol 151: 853-857

19. Muller A, Holzmann K, Kestler HA (2007) Visualization of genomic aberrations using Affymetrix SNP arrays. Bioinformatics 23: 496-497 
20. Nagaishi M, Kim YH, Mittelbronn M, Giangaspero F, Paulus W, Brokinkel B, Vital A, Tanaka Y, Nakazato Y, Legras-Lachuer C, Lachuer J, Ohgaki H (2012) Amplification of the STOML3, FREM2, and LHFP Genes Is Associated with Mesenchymal Differentiation in Gliosarcoma. Am J Pathol 180: 1816-1823

21. Nagaishi M, Paulus W, Brokinkel B, Vital A, Tanaka Y, Nakazato Y, Giangaspero F, Ohgaki H (2012) Transcriptional Factors for EpithelialMesenchymal Transition Are Associated with Mesenchymal Differentiation in Gliosarcoma. Brain Pathol 22: 670-676

22. Nigro JM, Takahashi MA, Ginzinger DG, Law M, Passe S, Jenkins RB, Aldape K (2001) Detection of $1 p$ and $19 q$ loss in oligodendroglioma by quantitative microsatellite analysis, a real-time quantitative polymerase chain reaction assay. Am J Pathol 158: 1253-1262

23. Nobusawa S, Lachuer J, Wierinckx A, Kim YH, Huang J, Legras C, Kleihues P, Ohgaki H (2010) Intratumoral patterns of genomic imbalance in glioblastomas. Brain Pathol 20: 936-944

24. Nobusawa S, Watanabe T, Kleihues P, Ohgaki H (2009) IDH1 mutations as molecular signature and predictive factor of secondary glioblastomas. Clin Cancer Res 15: 6002-6007

25. Nonoguchi N, Ohta T, Oh JE, Kim YH, Kleihues P, Ohgaki H (2013) TERT promoter mutations in primary and secondary glioblastomas. Acta Neuropathol 126: $931-937$

26. Ohgaki H, Dessen $P$, Jourde B, Horstmann S, Nishikawa T, Di Patre PL, Burkhard C, Schuler D, Probst-Hensch NM, Maiorka PC, Baeza N, Pisani P, Yonekawa Y, Yasargil MG, Lutolf UM, Kleihues P (2004) Genetic pathways to glioblastoma: a population-based study. Cancer Res 64: 6892-6899

27. Ohgaki H, Kleihues P (2007) Genetic pathways to primary and secondary glioblastoma. Am J Pathol 170: 1445-1453

28. Ohgaki H, Kleihues P (2013) The Definition of Primary and Secondary Glioblastoma. Clin Cancer Res 19: 764-772

29. Ohta T, Kim YH, Oh JE, Satomi K, Nonoguchi N, Keyvani K, Pierscianek D, Sure U, Mittelbronn M, Paulus W, Vital A, Yokoo H, McDonald K, Kleihues P, Nazaret N, Barbet F, Lachuer J, Ohgaki H (2014) Alterations of the RRAS and ERCC1 Genes at 19q13 in Gemistocytic Astrocytomas. J Neuropathol Exp Neurol 73: 908-915

30. Peraud A, Watanabe K, Schwechheimer K, Yonekawa Y, Kleihues P, Ohgaki H (1999) Genetic profile of the giant cell glioblastoma. Lab Invest 79: 123-129

31. Reis RM, Konu-Lebleblicioglu D, Lopes JM, Kleihues P, Ohgaki H (2000) Genetic profile of gliosarcomas. Am J Pathol 156: 425-432

32. Reuss DE, Mamatjan Y, Schrimpf D, Capper D, Hovestadt V, Kratz A, Sahm F, Koelsche C, Korshunov A, Olar A, Hartmann C, Reijneveld JC, Wesseling P, 
Unterberg A, Platten M, Wick W, Herold-Mende C, Aldape K, von DA (2015) IDH mutant diffuse and anaplastic astrocytomas have similar age at presentation and little difference in survival: a grading problem for WHO. Acta Neuropathol 129: 867-873

33. Schmidt MC, Antweiler S, Urban N, Mueller W, Kuklik A, Meyer-Puttlitz B, Wiestler OD, Louis DN, Fimmers R, von Deimling A (2002) Impact of genotype and morphology on the prognosis of glioblastoma. J Neuropathol Exp Neurol 61: $321-328$

34. Temme A, Geiger KD, Wiedemuth R, Conseur K, Pietsch T, Felsberg J, Reifenberger G, Tatsuka M, Hagel C, Westphal M, Berger H, Simon M, Weller M, Schackert G (2010) Giant cell glioblastoma is associated with altered aurora b expression and concomitant p53 mutation. J Neuropathol Exp Neurol 69: 632642

35. Watanabe T, Nobusawa S, Kleihues P, Ohgaki H (2009) IDH1 Mutations Are Early Events in the Development of Astrocytomas and Oligodendrogliomas. Am J Pathol 174: 1149-1153

36. Wiestler B, Capper D, Holland-Letz T, Korshunov A, von DA, Pfister SM, Platten M, Weller M, Wick W (2013) ATRX loss refines the classification of anaplastic gliomas and identifies a subgroup of IDH mutant astrocytic tumors with better prognosis. Acta Neuropathol 126: 443-451

37. Yan H, Parsons DW, Jin G, McLendon R, Rasheed BA, Yuan W, Kos I, BatinicHaberle I, Jones S, Riggins GJ, Friedman H, Friedman A, Reardon D, Herndon J, Kinzler KW, Velculescu VE, Vogelstein B, Bigner DD (2009) IDH1 and IDH2 mutations in gliomas. $N$ Engl $\mathrm{J}$ Med 360: 765-773 
Table 1 Clinical and genetic profile of the gliosarcoma and the giant cell glioblastoma, in comparison with primary and secondary glioblastoma

\begin{tabular}{|c|c|c|c|c|}
\hline 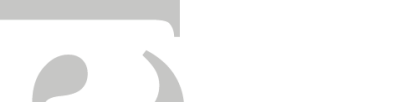 & $\begin{array}{c}\text { Primary glioblastoma } \\
\text { (IDH wild-type) }\end{array}$ & Gliosarcoma & $\begin{array}{c}\text { Giant cell } \\
\text { glioblastoma }\end{array}$ & $\begin{array}{c}\text { Secondary glioblastoma } \\
\text { (IDH mutant) }\end{array}$ \\
\hline Age at GBM diagnosis & 59 years $^{1,2,3,4}$ & 56 years $^{5}$ & 44 years $^{6,7}$ & 43 years $^{1,2,3,4}$ \\
\hline Sex ratio M/F & $1.4^{1,2}$ & $1.4^{5}$ & $1.6^{6}$ & $1.0^{1,2}$ \\
\hline Clinical history & 3.9 months $^{1}$ & 3.0 months $^{5}$ & 1.6 months $^{6}$ & 15.2 months $^{1}$ \\
\hline IDH1/2 mutation & $0 \%{ }^{1,8,9}$ & $0 \% *$ & $5 \% *$ & $100 \%{ }^{1,8,9}$ \\
\hline PTEN mutation & $24 \%^{1,8,9}$ & $41 \%^{5,10}$ & $33 \%{ }^{6}$ & $5 \%{ }^{1,8,9}$ \\
\hline ATRX expression loss & $0 \%{ }^{11}$ & $0 \% *$ & $19 \% *$ & $100 \%^{11}$ \\
\hline TERT mutation & $72 \%^{12,13,14}$ & $83 \% *$ & $25 \% *$ & $26 \%^{12,13,14}$ \\
\hline TP53 mutation & $23 \%^{1,8,9}$ & $25 \%^{5,10}$ & $84 \%{ }^{6,7,15}$ & $74 \%^{1,8,9}$ \\
\hline LOH 19q & $4 \%^{1}$ & $18 \% *$ & $42 \% *$ & $32 \%{ }^{1}$ \\
\hline EGFR amplification & $42 \%^{1,8,9}$ & $5 \% 5,10$ & $6 \% 6,7,15$ & $4 \%^{1,8,9}$ \\
\hline$p 16^{I N K 4 a}$ deletion & $45 \%^{1,8,9}$ & $37 \%^{5}$ & $3 \%{ }^{6,7}$ & $30 \%^{1,8,9}$ \\
\hline LOH $1 p$ & $15 \%^{1}$ & $6 \% *$ & $17 \%$ * & $24 \%^{1}$ \\
\hline $\mathrm{LOH} 1 p / 19 q$ & $2 \%^{1}$ & $6 \% *$ & $17 \%$ * & $11 \%^{1}$ \\
\hline $\mathrm{LOH} 10 \mathrm{q}$ & $67 \%{ }^{1}$ & $88 \% *$ & $50 \% *$ & $73 \%^{1}$ \\
\hline
\end{tabular}

* This study;

${ }^{1}$ Nobusawa et al. (24); ${ }^{2}$ Bleeker et al. (5); ${ }^{3}$ Ichimura et al. (12); ${ }^{4}$ Reuss et al. (32); ${ }^{5}$ Reis et al. (31); ${ }^{6}$ Peraud et al. (30); ${ }^{7}$ MeyerPuttlitz et al. (18); ${ }^{8} \mathrm{Gao}$ et al. (11); ${ }^{9}$ Cerami et al. (9); ${ }^{10}$ Actor et al. (1); ${ }^{11}$ Liu et al. (14); ${ }^{12}$ Nonoguchi et al. (25); ${ }^{13}$ Eckel-Passow et al. (10); ${ }^{14}$ Brennan et al. (8); ${ }^{15}$ Martinez et al. (17)

Typical for primary glioblastomas

Typical for secondary glioblastomas 
Fig. 1

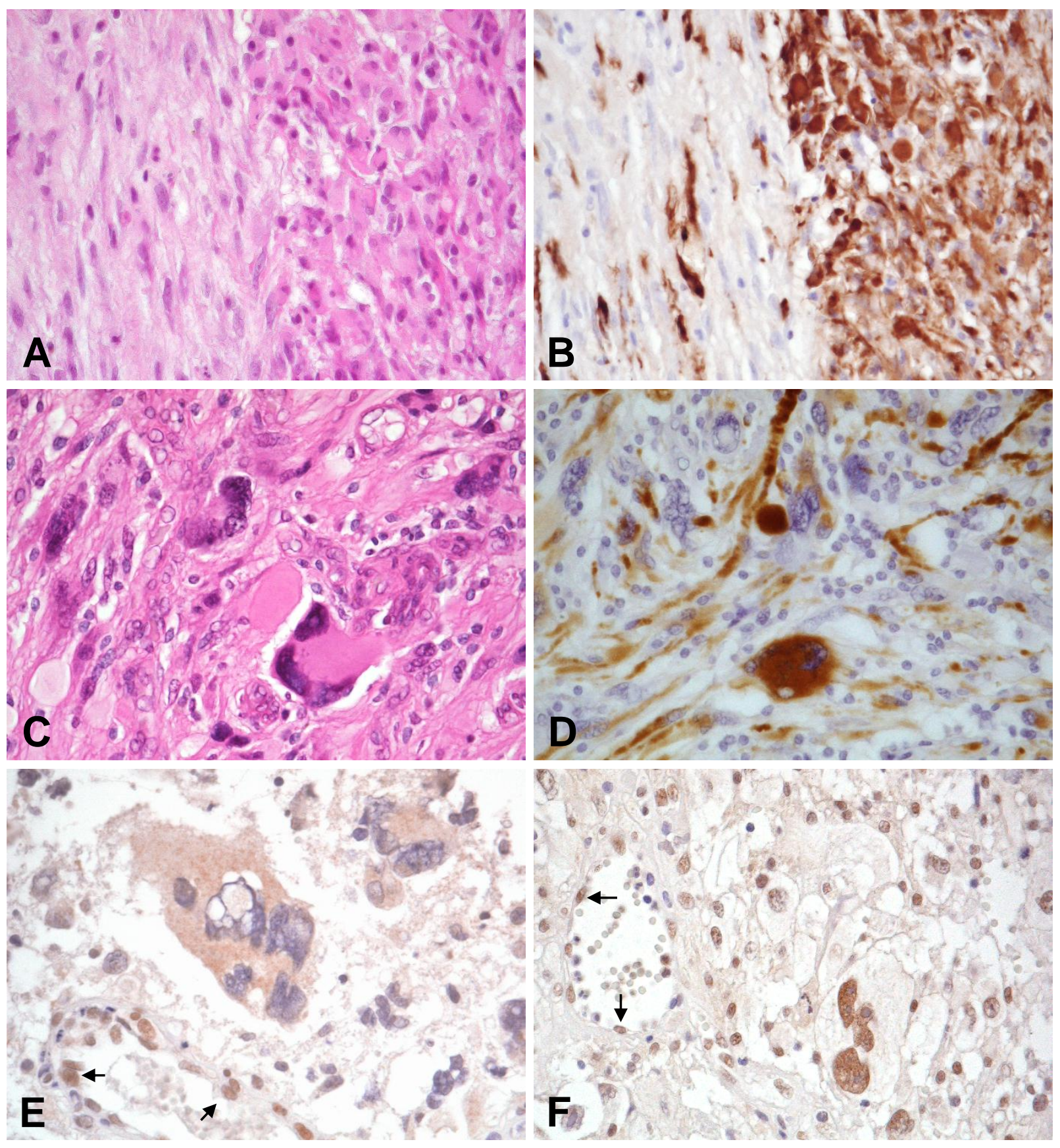

Brain Pathology Editorial Office, Blackwell Publishing, Oxford, UK 